\title{
Corrigendum: Validation and extension of the reward-mountain model
}

\section{Peter Shizgal*}

Psychology/Arts and Science, Center for Studies in Behavioural Neurobiology, Concordia University, Montreal, QC, Canada

*Correspondence: peter.shizgal@concordia.ca

Edited and reviewed by:

Angela Roberts, University of Cambridge, UK

Keywords: intracranial self-stimulation, brain stimulation reward, temporal integration, medial forebrain bundle, operant conditioning

\section{A corrigendum on}

Validation and extension of the rewardmountain model

by Breton, Y.-A., Mullett, A., Conover, K., and Shizgal, P. (2013). Front. Behav. Neurosci. 7:125. doi: 10.3389/fnbeh.2013. 00125

There is a subscripting error in the appendix to the article by Breton et al. (2013). In the sentence on page 16 between Equations A.6 and A.7 that begins

"Substituting for $U_{b s r}$ and $U_{e}$ in Equation A.5," the specified divisor should be $\frac{R I_{\max }}{S P \times(1+\xi)}$ and not $\frac{R I_{\max }}{S P_{e} \times(1+\xi)}$. In other words, there should be no subscript for $S P$ in the divisor.

\section{ACKNOWLEDGMENT}

The authors are grateful to Rebecca Solomon for spotting the error.

\section{REFERENCES}

Breton, Y.-A., Mullett, A., Conover, K., and Shizgal, P. (2013). Validation and extension of the rewardmountain model. Front. Behav. Neurosci. 7:125. doi: 10.3389/fnbeh.2013.00125

Conflict of Interest Statement: The authors declare that the research was conducted in the absence of any commercial or financial relationships that could be construed as a potential conflict of interest.

Received: 23 August 2014; accepted: 25 August 2014; published online: 11 September 2014.

Citation: Shizgal P (2014) Corrigendum: Validation and extension of the reward-mountain model. Front. Behav. Neurosci. 8:310. doi: 10.3389/fnbeh.2014.00310 This article was submitted to the journal Frontiers in Behavioral Neuroscience.

Copyright (c) 2014 Shizgal. This is an open-access article distributed under the terms of the Creative Commons Attribution License (CC BY). The use, distribution or reproduction in other forums is permitted, provided the original author(s) or licensor are credited and that the original publication in this journal is cited, in accordance with accepted academic practice. No use, distribution or reproduction is permitted which does not comply with these terms. 